\title{
Blended Learning Approach Using Moodle and Student's Achievement at Sultan Qaboos University in Oman
}

\author{
Wajeha Thabit Al-Ani ${ }^{1}$ \\ ${ }^{1}$ College of Education, Sultan Qaboos University, Muscat, Oman \\ Correspondence: Wajeha Thabit Al-Ani, College of Education, Sultan Qaboos University, P.O Box: 32, Postal \\ Code: 123, Al-Khoud, Muscat, Oman. Tel: 968-99-592-719. E-mail: wajeha@squ.edu.om
}

Received: June 25, 2013

Accepted: July 23, $2013 \quad$ Online Published: August 14, 2013

doi:10.5539/jel.v2n3p96

URL: http://dx.doi.org/10.5539/jel.v2n3p96

\begin{abstract}
This study attempts to identify factors behind the usage of a blended learning approach that could have an effect on students' achievement, motivation, collaboration and communication as perceived by students. It also aims to analyze obstacles faced by students in using Moodle in blended learning. A sample of 283-students from all colleges at Sultan Qaboos University was randomly selected. A questionnaire of 45 items is developed to collect data. The results reveal that using Moodle in blended learning has an average level of effectiveness related to students' motivation with a mean of 3.216 and mean of 3.164 for students' achievements, and mean of 3.199 is related to students' collaborations and communication. The results showed there is no statistical significant difference among student perceptions related to gender and college type. The results also revealed that the highest obstacles facing students related to frequent disturbance in computer devices with mean 3.090. Based on the result of the study, many recommendations have been developed.
\end{abstract}

Keywords: blended learning, moodle, student achievement, collaboration, communication

\section{Introduction}

Since Moodle was introduced as an opened source learning software, blended learning has been developed as another technical method in teaching beside the traditional face-to-face instruction (Dougiamas and Taylor, 2003). The expansion of the learning environment by using open source management system is supported by the social constructionist epistemologies theory (Andrews and Haythornthwaite, 2007). Its goal is to provide a set of tools that support an inquiry-and discovery-based approach, to create an environment that allows for collaborative interaction among students as a standalone or in addition to conventional classroom instruction. This theory focuses on sharing of opinions, ideas, and other social artifacts (Brandle, 2005).

Moreno et al. (2007) argue that the correct and effective use of technology in education must be supported by proven pedagogical and practical procedures based on computer supported collaborative learning and constructional learning. This approach generally involves discussion groups and building knowledge through activities closer to the real world. This practical real world situation is meaningful-learning contexts that give the students the opportunity to learn through a variety of approaches (Heckman et al., 2000).

Using Moodle in teaching develops learners' communicative skills in language and requires social interaction between the teacher and students and among the students themselves (Al-Ani, 2008). Siirak (2008) also argues that blended learning with computer based learning in a Moodle e-learning environment, based on social constructivist learning theory is an effective tool for teaching and learning in the occupational health and safety discipline.

The term e-learning (EL) course includes content "that is, information and instructional methods (that is, techniques) that help people learn content" (Clark and Mayer, 2008, p. 10). While the term blended learning is defined "as any mixture of any form of learning possible: classroom, virtual-classroom, or standalone e-learning" (Horton, 2006, p. 381). Kester et al. (2007) describe a system (using Moodle) that helps learners to match their knowledge with complementary content expertise in reaction to requests for knowledge sharing. The study showed the way that Moodle assists in hosting the community that enables learners to share their competence eligibility, availability and stimulates their social interaction.

E-learning has developed from a process focused on distributing information and knowledge to one that deeply 
engages learners in sophisticated interactions through communities that transcend geographic barriers (Liebowitz and Frank, 2011). This gives EL the benefit of exceeding the process of delivering knowledge. It strives to change students' behaviors, and increases content effectiveness. Though EL can be defined as "the acquisition and use of knowledge distributed and facilitated primarily by electronic means" (Waight et al., 2002, p. 492), Liebowitz and Frank (2011) state some of the other characteristics of e-learning. These characteristics are related to the root of the pedagogical framework of EL that has evolved from behaviorist theory in the late 1950s and 1960s to encompass a broader definition of "learning" that includes collaborative and constructivist paradigms of learning, including opportunities for practice with feedback, social collaboration, tailored instruction, simulation and games (Clark and Mayer, 2008).

In order to assure the transition to an e-learning environment, Liebowitz and Frank (2011) state that many significant challenges need to be faced such as:

1) Create and nurture acknowledge-sharing culture.

2) Support learners in adapting to change.

3) Design training and development to achieve the mission and advance competence.

4) Design education to prepare students to achieve success.

5) Develop learners to ask appropriate questions.

6) Provide needed relevant information just enough, just in time.

Because of these challenges of EL, learners are required to be more disciplined, self-motivated, and self-regulated than in a traditional classroom environment. Clark and Mayer (2008) add that e-learning will also increasingly make use of the unique technological features that can support simulations and good opportunities to learn. This technique will encourage learners to build mental models and problem solving skills relies on both cognitive and metacognitive skills. The advantage of this skill is to make learners more aware and to control their own learning process and increase their retention capacity (Liebowitz and Frank, 2011). Instructional design is considered as a ground theory for EL. It combines between the entire set of events and materials that affect learners for the purpose of accomplishing "a particular learning goal". This process must be carefully and systematically planned. Also, according to behavior learning objectives, if there is no teacher to instruct a person at the time, the ability to provide feedback can be constrained by available technology. Since EL requires highly motivated learners, it needs to increase the emphasis on a teaching presence in self-paced and highly interactive formats such as facilitated discussion or interactive environment such as wikis and blogs (Beldarrain, 2006).

\subsection{Problem Statement}

Since 2005, the Learning Management System (LMS) Moodle has been deployed as a major piece of technology at Sultan Qaboos University (SQU) for a blended learning approach to enhance students' achievement. Many courses have adopted this approach and the adoption rate reached 1362 in fall 2011. Blended learning is endorsed as a strategy that helps to create a more integrated approach for both instructors and learners. Since this is a new approach and method, it has obviously brought some changes in teaching and learning. To examine this, research needs to be done to measure its effectiveness on students' learning outcomes and achievements. Therefore, this study attempts to find out the effectiveness of creating blended learning using Moodle on students' learning achievements, motivation, and collaboration and communication.

\subsection{Research Objective}

Since this research aims to determine the effectiveness of a blended learning approach using Moodle and to determine students' achievement at SQU in Oman, therefore, it strives to achieve the following objectives:

1) To investigate to what extent a blended learning approach using Moodle could determine students' achievement in SQU in Oman.

2) To examine the dominant Moodle factors that lead to students' achievement.

3) To determine the obstacles facing blended learning approach using Moodle.

4) To know if there is any relationship between the blended learning approach using Moodle and these obstacles.

\subsection{Significance of the Study}

This study might provide insights that encourage SQU faculty members to utilize the emergent technology by using Moodle to improve the quality of teaching to enhance student learning achievements. Also, it may raise awareness among faculty members about the benefits of blended learning and its effectiveness on student 
learning achievements. The study findings will be useful in helping decision makers to determine the need for transforming the learning environment from face to face to blended learning in the University. It is expected that using Moodle will increase students' learning responsibility through social interaction (Bruner, 1990).

In addition, within the term of distance education, using Moodle will make the learning environment more meaningful through students' reflections and through developing their own procedures and techniques. Moreover, this research contributes to the relevant knowledge on ICT acceptance among students and their learning progress in the Omani context. It helps in creating opportunities by allowing students to participate and share ideas with their peers at the University. Last but not least, it assists instructors, lecturers and management to monitor students' achievement when it comes to Moodle usage.

\subsection{Theoretical Framework}

The use of socio-constructivist pedagogy has been identified as learning theory in the digital age where educators and students jointly explore, inquire, critique, and build their own knowledge effectively and efficiently (Lasic, 2011). Therefore the theoretical framework of this study is built on the constructivist theory that is about people knowing the world through their framework and helping them to organize as well as interpret their perceptions (Sackeny and Mergel, 2007).

\subsection{Conceptual Framework}

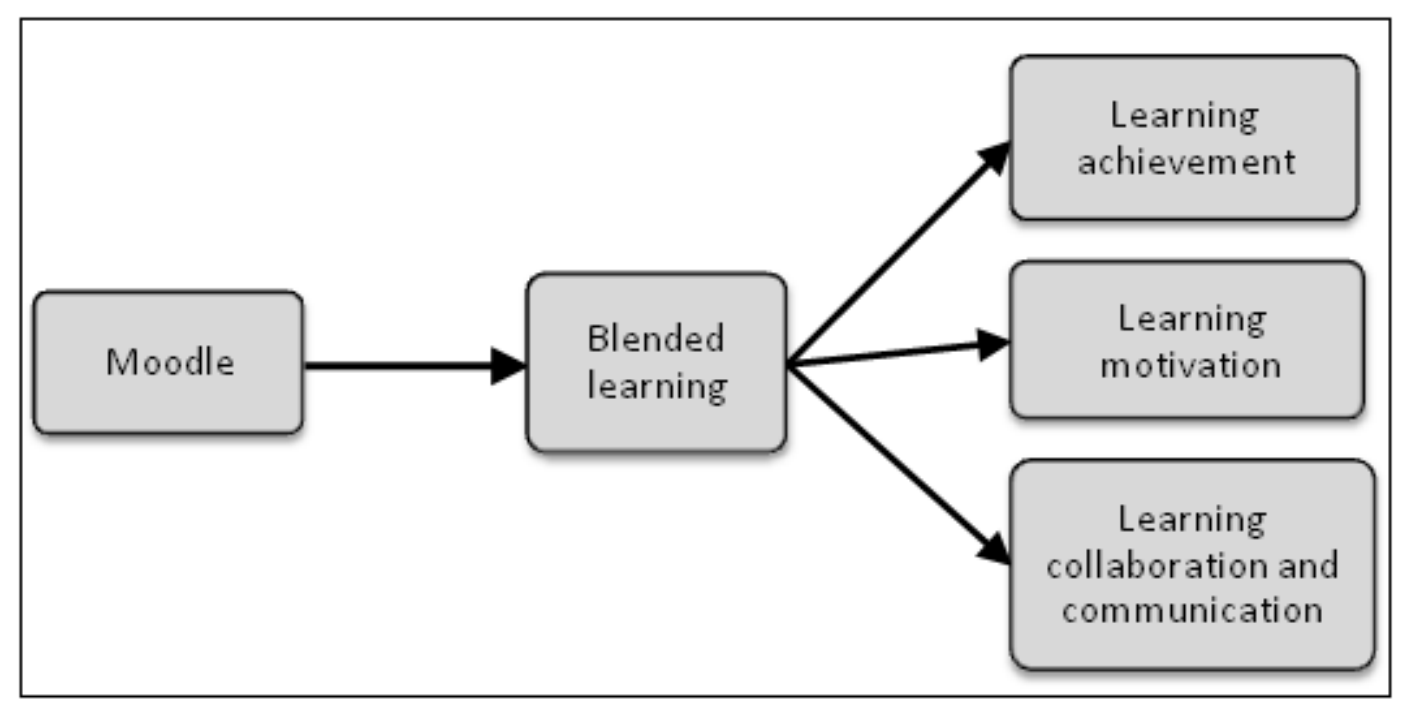

Figure 1. Research conceptual framework

Figure 1 presents the research conceptual framework using Moodle for blended learning to enhance students' learning achievement. The conceptual research framework was a developed base theory, a literature review and findings that stated that Moodle is e-learning software for learning management that could help teachers or educators to create interaction and collaboration with the course content. It is believed that, when Moodle is used, it helps blended learning to take place in mixing different learning environments where both Moodle and blended learning lead to students' learning achievement, learning motivation, collaboration and communication.

\subsection{Related Literature}

\subsubsection{Definitions}

Moodle stands for "Modular Object-Oriented Dynamic Learning Environment. "Moodle has already become a term of its own synonymous with a software package designed to help educators create quality online instruction. It was the brainchild of Martin Dougiamas. It is designed to help educators create quality online instruction" (Brandle, 2005, p. 16). Besides, Moodle is used interchangeably as a Learning Management System.

Blended learning is defined as "a combination of various instructional modalities intertwined with synchronous and/or asynchronous web-based technologies to facilitate interactive and reflective individual and collective learning" (Lupshenyuk and Adams, 2009, p. 428). 


\subsubsection{The Relationship between Blended Learning and Moodle}

Blended learning is commonly defended as an integration of traditional face-to-face and online approaches to instruction. Liebowitz and Frank (2011) define blended learning as a hybrid of traditional face-to-face and online learning instruction occurring both in classrooms and online and where the online component becomes a natural extension of traditional learning.

Research has proven that Moodle or (LMS) usage in the classroom enhances learning beyond the classroom for both teachers and learners (de Vega \& McAnally-Salas, 2010; Govender, 2009; Georgouli, Skalkidis \& Guerreiro 2008; Harman, 2007; Henderson 2010).

Additionally, it is proven that blended learning takes place when Moodle or a LMS is deployed. Besides, the application of Moodle or LMS, which was built on the Sociocultural-Constructivist learning model of (Melton, 2008), is believed to create a student-centered approach where students and instructors are both engaged and active in the classroom and use constructive learning activities.

\subsubsection{Blended Learning and e-Learning in Teaching}

The Al-Saleem et al. (2010) study was an attempt to investigate the effect of using blended learning on teaching English as a foreign language (EFL) on students' oral skills. The result of the study proved that blended learning enhanced significantly the EFL oral skills of the students of the experimental group due to the teaching procedures. This result is explained that blended learning exposed students to unlimited interaction with a language user, using sense of hearing, seeing and interacting. Also, the experimental groups were more interested in learning oral skills and that had a positive improvement in their achievements.

In a study of the importance of embedding e-learning in traditional universities, MacKeogh and Fox (2009) examine the possibility of linking e-learning with the achievement of strategic goals of traditional Irish universities (teaching is on-campus and face-to-face). This study examined the drives and barriers that increase or decrease motivation to engage in e-learning, and thus provided some insights into the challenges of embedding e-learning in higher education. The results of the study show that many academic staff continue to prefer traditional lectures, and are skeptical about the potential for student learning in online settings. Other obstacles related to extrinsic factors in terms of lack of time and support served to decrease motivation. There were also fears of loss of academic control to central administration. The study concluded with the importance of raising awareness and the establishment of effective support structures for embedding e-learning.

A study was conducted by Ellis et al. (2007) on the characteristics that shape a model to manage e-learning in a large predominantly campus-based university. The study illustrated key aspects of the management model providing insights into developing meaningful e-learning resources for students. The findings of the study revealed several challenges for quality improvement at the level of both course and university that (mainly due to the fact that e-learning complements the face-to-face learning experience) require a relational and embedded approach.

With regard to the motivational factors that influence the acceptance of a Moodle using Technology Acceptance Model (TAM), a study was conducted by Sanchez and Hueros (2010) that aimed to improve understanding of the motivational factors behind students' satisfaction or dissatisfaction with the web-based learning platform Moodle. 228 students were surveyed. The results showed that technical support directly perceived usefulness. Also, Moodle usage was directly influenced by perceived ease of use and attitude.

Bhattacharya and Sharma (2007) showed India's' extensive efforts to invest in information and communication technology (ICT) to enhance quality human resources in higher education in their developing nation. The study showed the challenges of traditional face-to-face education vis-à-vis e-learning in India. The challenges were listed and suggestions for management of e-learning processes by institutes which intend to venture into e-learning were enumerated. Also the study advocates the urgency for traditional institutions to invest in ICT. This will provide e-instruction for the delivery of knowledge by riding the information super highway.

With regard to successful blended learning, Mitchell and Honore (2007) highlight the factors that need to be considered when a blended learning solution is used in a group environment. The study showed that the importance of human behavioral factors regarding content and tool selection is very important. The role of group dynamics in achieving the learning outcomes also needs to be considered. Besides the learning experience, other learning methods experienced on the course are influenced partly by students' expectations and preferences.

1.6.4 Moodle for Learning Enhancement

Perkins and Pfaffman's (2006) study aims to show the benefits of using a Course Management System (CMS) to 
enable teachers to easily post assignments, lesson plans, announcements and course documents. The study highlighted the advantages of using Moodle as a free open-source software program that not only provides a set of features similar to those of its proprietary competitors, it is often easier to use. The study describes how Moodle has improved and enhanced student performance by promoting and organizing communication among parents, students, teachers, administrators, and the community. Using CMS can help to reduce distractions and roadblocks to science learning and improve communication with colleagues, students, and parents.

With regards to the design of a competitive and collaborative learning strategy, Regueras et al. (2011) found out that using the Moodle Wiki encourages the development of students' inquiry, documentation and critical analysis skills and raises the level of involvement and communication between students and teachers. While Konstantinidis et al. (2011) argue that the rationale behind the utilization of Moodle for the facilitation of a blended learning approach in the informatics departments is the help it offers to a variety of instructor and student needs.

From the above reviewed literature, it can be concluded that transferring to an e-learning environment is one aspect of restructuring learning strategies by showing more concern for learners, and giving them more space for effective involvement in the learning process. This is done through using the open software e-learning platform Moodle. Regarding the blended learning in higher education, the Lopez-Perez et al. (2011) study shows that the use of blended learning has a positive effect on reducing dropout rates and in improving exam marks. Moreover, the students' perceptions of blended learning are interrelated with their final marks depending on the blended learning activities and on the students' age, background and class attendance rate.

\subsubsection{Supported Models}

Looking at the effectiveness of using Moodle in teaching, many models have been developed. Woltering et al. (2009) show a module that enhances students' motivation and satisfaction and overcomes problems named Blended Problem-Based Learning (BPBL). A total of 185 third-year students and 14 tutors took part in this study. The results show motivation, subjective learning gains and satisfaction were all awarded significantly higher ratings by BPBL students compared with students' learning by traditional problem-based learning. The BPBL module also improves cooperation during self-directed learning. Another blended Model was developed by McLuckie et al. (2009) using the open-source e-learning platform Moodle. The model was used to support students' and professionals' learning when face-to-face contact time between students and tutors was significantly is reduced. The study results show that the use of collaborative and peer-assessed tools like e-portfolios, newsletters, discussion forums, Wikis and group puzzles can be used as means to satisfy demands; and that this approached reflects the socially constructivist principles of learning. 


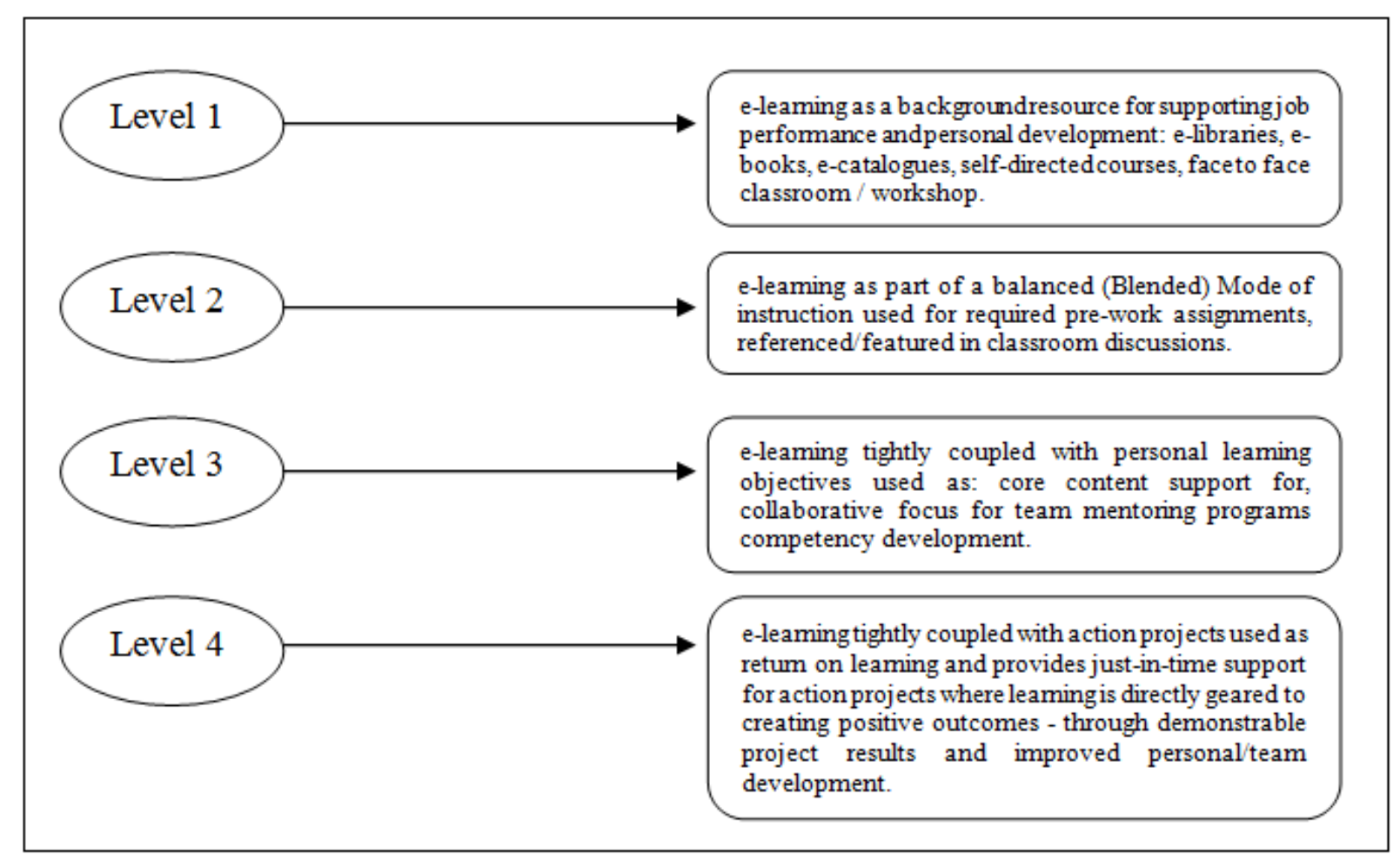

Figure 2. Blended Learning 4 Level Models and Online Learning

Figure 2 complements this research on blended learning using Moodle. It supports the idea and the relationship of blended learning with e-learning. It shows that blended learning is effective and efficient when it is applied online or as Moodle. The levels in figure 2 indicate that blended learning with the online learning integration facilitates learning, communication and provides e-material to support learning. The 4 blended learning models upgrades instruction and help students' engagement in the classroom, assignments, collaboration, supervision of projects and development.

\subsubsection{Challenges of Blended Learning Using Moodle}

Higher education institutions face many challenges in teaching as they increasingly move to blended and fully online environments. Banerjee (2011) indicates that student satisfaction with blended learning depends largely on the challenges presented by the subject matter, the degree to which self directed learning and problem solving are required and the effectiveness of the chosen pedagogies by which face-to-face and online methods are combined. Also blended environments, which provide sustained connections with teachers and peers are preferred by increasing the number of students. Shivetts (2011) mentions that student motivation is a major factor for e-learning and blended learning success. This success is heavily related to course layout and accessibility. Showing the effectiveness of using Moodle in blended learning is very helpful in assessing students' vocabulary acquisition. Jia et al. (2012) customized Moodle to build individualized vocabulary review and assessment functions of English instruction. Within this blended learning environment, students' performance in an experimental class in the ordinary, and especially vocabulary, examinations throughout the school term gradually improved and exceeded that of the control class.

Seung-Won and Lim (2007) present a conceptual framework for Strategic Blended-Learning and Performance Solution (SBLPS). This model was designed to improve learning performance solutions derived from the goals and needs of their organization. Deeb (2007) shows that involving students in web-blended learning activities support significant improvement in their academic performance, and advancement in their collective and intuitive knowledge at both social and technical levels.

\subsection{Research Questions}

The study intended to answer the following questions:

1) What is/are the dominant Moodle factor(s) that lead mostly to students' achievements as perceived by the 
students?

2) What are the obstacles faced by students in the blended learning approach using Moodle in learning?

3) Are there any statistically significant relationships between the students' usage of Moodle in learning and the obstacles facing them?

\section{Method}

This study attempted to investigate university students' uses of open source learning software (Moodle) in learning in the way that activated their achievements. This study looks to Moodle as software that helps teachers at SQU to create an effective blended learning environment. Also, it is used as a support tool to help students to experience and build knowledge through exchanging ideas and information among themselves and with their teacher.

\subsection{Data Collection Procedure}

The research population consisted of students from SQU in Oman. SQU is the national governmental university in Sultanate of Oman, established in 1986. It consists of nine colleges and the English Language Center (www.squ.edu.om). It also has a large Center for Educational Technology as a service teaching facilitation center. Throughout its history, the university has been concerned about quality assurance in its academic program. In order to accomplish this, SQU has developed a strategic policy that attempts to enhance the university learning environment by equipping all teaching rooms and offices with computer facilities and services. This study examined the uses of Moodle at SQU since its first introduction in 2005. The number of e-learning courses has increased rapidly and has reached 1362 courses, $46 \%$ of the total 2953 courses offered at SQU at the time this research was conducted in the Spring Semester 2012. The e-learning courses are offered at different levels and are multi service courses that meet students' needs and interests. However, not all courses were actively using Moodle at the time of research data collection. Thus, a random sample from the active courses was chosen. A total of 18 instructors representing 18 courses that use blended learning using Moodle in teaching agreed to distribute the questionnaire to their students during regular classes. The courses were chosen with consideration to college type (Humanities and Sciences). An average number of 15-16 students from each course were asked voluntarily to participate in the study.

\subsection{Sample}

A sample of 283-students from all colleges at SQU was randomly selected in the Spring Semester 2012. This sample represents the students who are using Moodle as a type of blended learning on the courses. The description of the study sample is shown in table 1 .

Table 1. The demographic description of the study sample

\begin{tabular}{llll}
\hline Variables & Types & Number & Percentage \\
\hline \multirow{2}{*}{ Gender } & Male & 147 & $51.9 \%$ \\
& Female & 136 & $48.1 \%$ \\
Colleges & Humanities & 165 & $58.3 \%$ \\
& Sciences & 118 & $41.7 \%$ \\
\multirow{2}{*}{ Accommodation } & Inside campus & 105 & $37.1 \%$ \\
& Outside campus & 178 & $62.9 \%$ \\
\hline Total & & 283 & $100.0 \%$ \\
\hline
\end{tabular}

\subsection{Research Instrument}

The main instrument of this study was a questionnaire developed by generating a list of factors derived from the literature (Sambrook, 2003; Brandle, 2005; and Mazza and Botturi, 2007). These factors are learning achievement, learning motivation, and students' collaboration and communication learning skills. Beside these statements, the questionnaire included a list of obstacles (14-items) that face students in using Moodle in learning.

The instrument for the study was validated by a group of specialists in the area of educational learning and instruction, educational technology, educational administration, and education psychology in the College of 
Education at SQU.

A Liker-type scale ranging from $1=$ very low to $5=$ very high was used to measure students' responses on the uses of Moodle in learning. A theoretical mean of 3.00 (mid-point of the scale) was determined as the criterion to judge the means. A list of 14 obstacles facing students in using Moodle in learning was developed on a scale from $0=$ the lowest to $5=$ the highest degree.

To determine the reliability of the instrument, a random sample of 30 students was selected and the Chronbach-Alpha was found to be 0.961 on the total items, 0.912 for learning achievement, 0.902 for learning motivation and 0.903 for students' collaboration and communication.

\section{Results}

This study attempted to identify the factors that affected student achievement during their use of the open source learning software Moodle. These factors are distributed in three domains as shown in table 2.

Table 2. Means and Standard Deviation (SD) and Rank of Study domains

\begin{tabular}{llll}
\hline Domains & Means & SD & Rank \\
\hline Students' Learning Achievement (LA) & 3.164 & .653 & 3 \\
Students' Learning Motivation (LM) & 3.216 & .800 & 1 \\
Students' Collaboration and Communication (SCC) & 3.199 & .754 & 2 \\
\hline Total & 3.188 & .651 & \\
\hline
\end{tabular}

The result of the first question reveals that using Moodle in learning is around the average level of effectiveness according to the theoretical mean of 3.00 as a criterion to judge the result. These means ranged from 3.216 , the highest mean of the distribution for using Moodle makes students more motivated toward learning, followed by student collaboration and communication 3.199. Finally, students' learning achievement is rated at 3.164.

The result of the student responses (Appendix I) shows that students look at Moodle as a learning tool that allows them more freedom in choosing a suitable time for doing their homework (3.69). The blended learning approach using Moodle also helps students to develop their learning skills (3.46) and be more self regulated (3.31) in searching for new scientific information (3.42). Looking at the results of the learning motivation domain, students find the blended learning approach using Moodle interesting in tracking lecture notes and reading materials (3.28). In addition, students feel that using Moodle helps them in developing positive attitudes toward course subjects (3.30).

With reference to the student collaboration and communication domain, students explained that using Moodle made their lecture notes (3.91) and develop their skills in browsing throughout websites searching for information (3.73).

Also, the results in table 3 show that there are statistically significant differences at $(\alpha=0.05)$ between the mean of students' responses related to gender in the collaboration and communication domain in favor females (3.303) compared with males (3.103).

Table 3. The Result of t-test in testing study variables

\begin{tabular}{llllllc}
\hline Domains & Variables & $\mathrm{N}$ & Mean & SD & t-test & $\begin{array}{c}\text { Significant } \\
\text { (2-tailed) }\end{array}$ \\
\hline LA & Male & 147 & 3.1139 & .62353 & -1.345 & .180 \\
& Female & 136 & 3.2183 & .68278 & & \\
& Humanities & 165 & 3.1899 & .67998 & .786 & .432 \\
& Sciences & 118 & 3.1279 & .61587 & & \\
& Inside campus & 105 & 3.1689 & .68163 & .096 & .924 \\
& Outside campus & 178 & 3.1612 & .63844 & & \\
\hline
\end{tabular}




\begin{tabular}{|c|c|c|c|c|c|c|}
\hline \multirow[t]{6}{*}{ LM } & Male & 147 & 3.1634 & .76257 & -1.148 & .252 \\
\hline & Female & 136 & 3.2727 & .83931 & & \\
\hline & Humanities & 165 & 3.1910 & .79522 & -.618 & .537 \\
\hline & Sciences & 118 & 3.2507 & .81067 & & \\
\hline & Inside campus & 105 & 3.2160 & .81965 & .002 & .999 \\
\hline & Outside campus & 178 & 3.2158 & .79182 & & \\
\hline \multirow[t]{6}{*}{$\mathrm{SCC}$} & Male & 147 & 3.1032 & .74813 & -2.243 & $* .026$ \\
\hline & Female & 136 & 3.3030 & .74928 & & \\
\hline & Humanities & 165 & 3.2214 & .71696 & .585 & .559 \\
\hline & Sciences & 118 & 3.1682 & .80507 & & \\
\hline & Inside campus & 105 & 3.2275 & .74610 & .485 & .628 \\
\hline & Outside campus & 178 & 3.1825 & .76024 & & \\
\hline
\end{tabular}

*Significant at $(\alpha=0.05)$

In regards to the second question that investigated the obstacles facing students in using Moodle in learning, Table 4 shows the mean score of student responses.

Table 4. Means and SD of obstacles as perceived by students

\begin{tabular}{llcc}
\hline No & Student faced the following obstacles: & Mean & SD \\
\hline 4 & Frequent disturbance in computer devices. & 3.09 & 1.825 \\
6 & Frequent disturbed in university network. & 2.65 & 1.751 \\
1 & Faced difficulties during studying on the computer. & 2.45 & 1.721 \\
3 & Feel worried in doing online quizzes. & 2.38 & 1.835 \\
2 & Does not have enough time to do the homework. & 2.26 & 1.598 \\
9 & There is no technical support or guidance in the lab. & 1.70 & 1.721 \\
7 & Does not have enough knowledge about using Moodle. & 1.37 & 1.504 \\
10 & Does not have typing and editing skills. & 1.02 & 1.414 \\
8 & Does not have computer skills. & 1.01 & 1.419 \\
5 & Does not have a personnel computer. & .75 & 1.467 \\
\hline
\end{tabular}

Table 4 shows that there are many obstacles facing students using Moodle in learning. Some of those obstacles are related to the network disruption with a mean of (3.09) followed by defects in the university network (2.65). Other obstacles related to students facing difficulties in learning at the computer screen (2.45) and feeling worried when doing online quizzes (2.38).

In order to answer the third question that aimed to determine the relationship between students' responses to using Moodle in Learning and the obstacles they faced, a Pearson correlation test was conducted, as shown in Table 5. 
Table 5. The Result of Pearson Correlation Coefficient to student responses

\begin{tabular}{llcccc}
\hline \multirow{2}{*}{ Domains } & & LA & LM & SCC & Obstacles \\
\hline LA & Pearson Correlation & 1 & $.778^{* *}$ & $.656^{* *}$ & .012 \\
& Sig. (2-tailed) & & .000 & .000 & .834 \\
& $\mathrm{~N}$ & 283 & 283 & 283 & 283 \\
LM & Pearson Correlation & $.778^{* *}$ & 1 & $.724^{* *}$ & .016 \\
& Sig. (2-tailed) & .000 & & .000 & .792 \\
& $\mathrm{~N}$ & 283 & 283 & 283 & 283 \\
SCC & Pearson Correlation & $.656^{* *}$ & $.724^{* *}$ & 1 & .114 \\
& Sig. (2-tailed) & .000 & .000 & & .056 \\
& $\mathrm{~N}$ & 283 & 283 & 283 & 283 \\
Obstacles & Pearson Correlation & .012 & .016 & .114 & 1 \\
& Sig. (2-tailed) & .834 & .792 & .056 & \\
& $\mathrm{~N}$ & 283 & 283 & 283 & 283 \\
\hline
\end{tabular}

**Correlation is significant at the 0.01 level (2-tailed).

The results in Table 5 show that there is a statistically significant correlation $(\alpha=0.01)$ between LA and LM $(\mathrm{r}=0.778)$ and between LA and SCC $(\mathrm{r}=0.656)$, and the same applies between LM and SCC (0.724). The results show that there is no statistically significant correlation of student responses to the study domains and obstacles.

\section{Discussion}

This study aimed to determine the relationship between university student perceptions in using Moodle and their LA, LM, and SCC, as well as to identify some obstacles that affect student usage of Moodle in learning. The results of the study revealed that using Moodle in learning increased students' achievements and self regulated skills. These results are in line with those of Al-Saleem et al. (2010) and Vovides et al. (2007) that in blended learning classes, the environment is comfortable, cooperative, not threatening, and reduces psychological barriers such as stress, anxiety. Through rich communicative blended learning activities the students' path to self-regulation is supported.

As far as the learning motivation factor is concerned, many studies have indicated that this factor is essential. It impacts on student achievement and increases students' motivation to learn. The result of this study shows that there is a positive correlation $(\mathrm{r}=0.778)$ between students' learning motivation and their achievements. Students show that they can follow their lecture notes and do additional readings, while maintaining a positive attitude towards learning. This finding is supported by Lupshenyuk and Adams (2009) who indicate that blended learning has a positive impact on workplace learners' motivation to learn. These results are also supported by Al-Saleem et al. (2010) who report that a blended learning context provides students with opportunities to think and rethink, get prompt feedback, decreases peer-pressure, and increases self-esteem.

Pearson and Trinidad (2005) have indicated that changing the learning environment to an e-learning style can result in improving students' achievement affective and cognitive learning outcomes. Student responses to the collaborative and communicative domain with a mean of (3.199) reveals that this type of learning environment helps students to support each other in project work or homework. The flexibility of using computers in learning helps students to download lecture notes and learn material easily. It develops their skills in browsing through different websites when searching for extra information. These results are supported by constructivist theory that places emphasis on learning contexts that help students to experience and build knowledge. Also this theory emphasizes the social dimension of education, encouraging students to work in a humanistic environment that establishes the best results that can be obtained through activity and experience (Moreno et al., 2007).

Finally, these results of this study show that SQU students are interested in using Moodle to learn through 
developing their skills, meet their learning needs, and support their own self-regulation. These results are supported by Vovides et al. (2007) who state that teaching students in a rich computer aided environment had a positive effect in increasing academic achievement. It helped students to hear, see, reflect, and interact in a more communicative and collaborative learning environment.

\section{Research Implication}

The results of this study provide supporting evidence to move forward towards a blended learning environment using Moodle at SQU. Students' responses have shown the effectiveness that using Moodle has on their learning motivations, achievements and collaboration and communication skills. The results also demonstrate that using blended learning will help students to be more self-regulated and self-directed by reducing the number of days and hours spent in traditional face-to-face learning environments.

Blended learning will help students at university level to be more reflective learners as they engage in a heavily customized, personalized learning environment. Since this type of learning is supported by constructivist theory that focuses on learning contexts, it will give more opportunity for student at the university level to interact with course materials, with instructors, and with other students. This will help students to experience and build knowledge.

To assure high quality in teaching, the study reveals the need for professional development of faculty members at SQU, so that they become more familiar with the blended learning approach and are enabled to move smoothly towards a web-base-learning environment.

\section{Conclusion}

The results of this study provide support for transforming traditional learning into a blended learning environment at SQU. The findings of this study indicate that using Moodle in learning can develop students' self-regulated skills, and to become inquiring learners by searching for new information and knowledge. The flexibility of this type of learning environment increases student motivation and their desire to learn to meet their achievement goals.

Looking at the SCC domain, students show that using Moodle in learning expands the social context of learning through sharing their knowledge, supporting each other and having more time for discussion and reflections. In spite of some obstacles facing students who use Moodle in learning, students' responses show that these barriers can be overcome if SQU assigns more technical support to computer labs. This would help students to solve technical problems. The results also show that those obstacles have no significant correlation to the LM, LA, and SCC domains in the study. This indicates that using Moodle in learning has more impact on student-centered learning techniques that make students more active and motivated. Students also demonstrate a greater willingness to share and collaborate with their peers and teachers.

The items included in LM, LA and SCC domains as outcomes of this study might be further developed as tools to assess effective teacher use of Moodle in a similar environment such as a private university in the Sultanate of Oman. At the same time the data collected might provide the service Center of Educational Technology (CET) at SQU with some information that helps in designing workshops for the teaching staff from different colleges to develop their skills using Moodle in teaching. These results will help decision makers at the university to increase courses using Moodle in teaching. It might also encourage them to reconsider the role of traditional education and consider open distance learning.

\section{References}

Al-Ani, W. (2008). English as foreign language student teachers' perception of the use of Moodle in foundations of education course. Malaysian Journal of Learning and Instruction, 5, 63-78.

Al-Saleem, B. I., Samadi, O. M., \& Tawalbeh, M. A. (2010). The effect of using blended learning on EFL Jordanian tenth grades student's oral skills (pp. 99-128). Proceedings of Education in the Era of Alternatives Conference. Yarmook University, Jordan, 20-22 April.

Andrews, R., \& Haythornthwaite, C. (2007). Introduction to E-learning Research. In R. Andrews, \& C. Haythornthwaite (Eds.), The SAGE Handbook of E-learning Research (pp. 1-52). SAGE Publications, Los Angeles USA.

Banerjee, G. (2011). Blended environments: Learning effectiveness and student satisfaction at a small college in transition. Journal of Asynchronous Learning Networks, 15(1), 8-19. Retrieved from http://search.proquest.com/docview/864941638?accountid=27575

Beldarrain, Y. (2006). Distance education trends: Integrating new technologies to foster student interaction and 
collaboration. $\quad$ Distance Education, $\quad 27(2), \quad$ 139-153. $\quad$ Retrieved from http://search.proquest.com/docview/217795397?accountid=27575

Bhattacharya, I., \& Sharma, K. (2007). India in the knowledge economy - an electronic paradigm. The International Journal of Educational Management, $\quad$ 21(6), http://dx.doi.org/10.1108/09513540710780055

Brandle, K. (2005). Are you ready to Moodle?. Language Learning Technology, 9(2), 16-23. Retrieved from http://1lt.msu.edu/vol9num2/review1/default.html

Bruner, J. (1990). Acts of Meaning. Cambridge, MA: Harvard University Press.

Clark, R. C., \& Mayer, R. E. (2008). E-learning and science of instruction: proven guidelines for consumers and designers of Multimedia learning. Pfeiffer San Francisco CA, USA.

Deeb, K. K. (2007). The impact of social technologies on student performance in a collaborative learning environment. International Journal of Teaching and Case Studies, 1(1), 121-134. http://dx.doi.org/10.1504/IJTCS.2007.014214

de Vega, C., \& McAnally-Salas, L. (2010). Online Support for a Chemistry Course: The Opinion of University Freshmen (pp. 36-46). Proceedings of the $5^{\text {th }}$ International Conference on e-Learning, Penang, Malaysia.

Dougiamas, M., \& Taylor, P. (2003). Moodle: Using learning communications to create and open source course management system, EDMEDIA, Retrieved September 7 2011, from http://dougiamas.com/writing/edmedia2003

Ellis, R. A., Jarkey, N., Mahony, M. J., Peat, M., \& Sheely, S. (2007). Managing quality improvement of eLearning in a large, campus-based university. Quality Assurance in Education, 15(1), 9-23. http://dx.doi.org/10.1108/09684880710723007

Georgouli, K., Skalkidis, I., \& Guerreiro, P. (2008). A framework for adopting LMS to introduce e-learning in a traditional course. Educational Technology \& Society, 11(2), 227-240. Retrieved from http://search.proquest.com/docview/61949470?accountid=27575

Govender, I. (2009). The learning context: Influence on learning to program. Computers \& Education, 53(4), 1218-1230. Retrieved from http://search.proquest.com/docview/61858935?accountid=27575

Harman, C. (2007). Is this op-amp any good?: Lab-built checker removes all doubt! Tech Directions, 67(5), 14-17. Retrieved from http://search.proquest.com/docview/61965147?accountid=27575

Heckman, R., Maswick, D., Rodgers, J., Ruthen, K., \& Wee, G. (2000). The impact of Information Technology on Roles and Role Processes in Small Groups. In L. A. Petrides (Eds.), Case Studies on Information Technology in Higher Education: Implications for Policy and Practice (pp. 157-167). IDEA Group Publishing, Hershey USA.

Henderson, J. G. (2010). Learning through a disciplined curriculum study approach: Implications for educational leadership. Scholar-Practitioner Quarterly, 4(4), 312-315. Retrieved from http://search.proquest.com/docview/964183745? accountid=27575

Horton, W. (2006). E-Learning by Design. Published by Pfeiffer San Francisco CA, USA.

Jia, J., Chen, Y., Ding, Z., \& Ruan, M. (2012). Effects of a vocabulary acquisition and assessment system on students' performance in a blended learning class for english subject. Computers \& Education, 58(1), 63-76. Retrieved from http://search.proquest.com/docview/964184651?accountid=27575

Kester, L., van Rosmalen, P., Sloep, P., Brouns, F., Kone, M., \& Koper, R. (2007). Matchmaking in learning networks: Bringing learners together for knowledge sharing. Interactive Learning Environments, 15(2), 117-126. Retrieved from http://search.proquest.com/docview/62050811 accountid=27575

Konstantinidis, A., Papadopoulos, P. M., Tsiatsos, T., \& Demetriadis, S. (2011). Selecting and evaluating a learning management system: A moodle evaluation based on instructors and students. International Journal of Distance Education Technologies, 9(3), 13-30. Retrieved from http://search.proquest.com/docview/902064199?accountid=27575

Lasic, T. (2011). Cover of discover Moodle 2.0 from a pedagogical aspect, SQU E-learning day (p. 2).

Liebowitz, J., \& Frank, M. (2011). Knowledge Management and E-learning. Auerbach Publications, Taylor \& Francis Group, LLC. USA.

Lopez-Perez, V., Perez-Lopez, C., \& Rodriguez-Ariza, L. (2011). Blended learning in higher education: Students' 
perceptions and their relation to outcomes. Computers \& Education, 56(3), 818-826. Retrieved from http://search.proquest.com/docview/851228898?accountid=27575

Lupshenyuk, D., \& Adams, J. (2009). Workplace learners' perceptions towards a blended learning approach. In C. Ardil (Ed.), Proceedings of World Academy on Science, Engineering, and Technology (pp. 536-540).

MacKeogh, K., \& Fox, S. (2009). Strategies for embedding e-learning in traditional universities: Drivers and barriers. Electronic Journal of e-Learning, 7(2), 147-154. Retrieved from $\mathrm{http}: / /$ search.proquest.com/docview/61820480?accountid=27575

Mazza, R., \& Botturi, L. (2007). Monitoring an online course with the GISMO tool: A case study. Journal of Interactive Learning Research, 18(2), 251-265. Retrieved from http://search.proquest.com/docview/211230304?accountid=27575

McLuckie, J. A., Naulty, M., Luchoomun, D., \& Wahl, H. (2009). Scottish and Austrian perspectives on delivering a master's: From paper to virtual and from individual to collaborative. Industry and Higher Education, 23(4), 311-318. Retrieved from http://search.proquest.com/docview/61849202?accountid=27575

Melton, J. (2008). Need an LMS? Try the Open Source Package Moodle. Journal of Instruction Delivery Systems, 22(1), 18-21. Retrieved from http://jklmelton.net/annual/2008/jids/

Mitchell, A., \& Honore, S. (2007). Criteria for successful blended learning. Industrial and Commercial Training, 39(3), 143-149. http://dx.doi.org/10.1108/00197850710742243

Moreno, L., Gonzalez, C., Castilla, I., Gonzalez, E. J., \& Sigut, J. (2007). Use of constructivism and collaborative teaching in an ILP processors course. IEEE Transactions on Education, 50(2), 101-111. http://dx.doi.org/10.1109/TE.2006.886461

Pearson, J., \& Trinidad, S. (2005). OLES: An instrument for refining the design of e-learning environments. Journal of Computer Assisted Learning, 21(6), 396-404. Retrieved from http://search.proquest.com/docview/222644792?accountid=27575

Perkins, M., \& Pfaffman, J. (2006). Using a course management system to improve classroom communication. Science Teacher, 73(7), 33-37. $\quad$ Retrieved from http://search.proquest.com/docview/62029987?accountid=27575

Regueras, L. M., Verdu, E., Verdu, M. J., \& de Castro, J. P. (2011). Design of a competitive and collaborative learning strategy in a communication networks course. IEEE Transactions on Education, 54(2), 302-307. http://dx.doi.org/10.1109/TE.2010.2053933

Sackeny, L., \& Mergel, B. (2007). Contemporary learning theories, instructional design and leadership, constructs of thinking education leaders. Edit by John M. Burger and Charles F., Webber published by Springer.

Sambrook, S. (2003). E-learning in small organisations. Education \& Training, 45(8), 506-516. Retrieved from $\mathrm{http}: / /$ search.proquest.com/docview/237069532?accountid=27575

Sanchez, R. A., \& Hueros, A. D. (2010). Motivational factors that influence the acceptance of moodle using TAM. Computers in Human Behavior, 26(6), 1632-1640. http://dx.doi.org/10.1016/j.chb.2010.06.011

Seung-Won, Y., \& Lim, D. H. (2007). Strategic blending: A conceptual framework to improve learning and performance. International Journal on ELearning, 6(3), 475-489. Retrieved from $\mathrm{http}: / /$ search.proquest.com/docview/210328750?accountid=27575

Shivetts, C. (2011). E-learning and blended learning: The importance of the learner--A research literature review. International Journal on E-Learning, 10(3), 331-337. Association for the Advancement of Computing in Education. P.O. Box 1545, Chesapeake, VA 23327-1545. Retrieved from http://search.proquest.com/docview/898325941?accountid=27575

Siirak, V. (2008). Moodle e-learning environment: An effective tool for a development of a learning culture. Institution of Chemical Engineers Symposium Series, 154, 290-296.

Vovides, Y., Sanchez-Alonso, S., Mitropoulou, V., \& Nickmans, G. (2007). The use of e-learning course management systems to support learning strategies and to improve self-regulated learning. Educational Research Review, 2(1), 64-74. http://dx.doi.org/10.1016/j.edurev.2007.02.004

Waight, C. 1., Willging, P. A., \& Wentling, T. L. (2002). Recurrent themes in e-learning: A meta-analysis of major e-learning reports. In Proceeding from the Academy of Human Resourced Development Conference (pp 
491-499).

Woltering, V., Herrler, A., Spitzer, K., \& Spreckelsen, C. (2009). Blended learning positively affects students' satisfaction and the role of the tutor in the problem-based learning process: Results of a mixed-method evaluation. Advances in Health Sciences Education, 14(5), 725-738. Retrieved from http://search.proquest.com/docview/61839897?accountid=27575

\section{Appendix I}

Table 1. Means and SD of students' responses for Learning Achievements (LA) domain statements

\begin{tabular}{|c|c|c|c|}
\hline No & Statements & Mean & $\mathrm{SD}$ \\
\hline q13 & Gives me more freedom in choosing an appropriate time to do the assignments. & 3.69 & 1.117 \\
\hline q9 & Develops my skills in self-management. & 3.46 & 1.010 \\
\hline q10 & Develops my ability for searching new scientific information. & 3.42 & 1.015 \\
\hline q15 & Develops my typing and editing skills. & 3.42 & 1.106 \\
\hline q6 & Increases my desire to do homework in electronic way rather than paper. & 3.26 & 1.168 \\
\hline q7 & Increases my knowledge in the area of study. & 3.20 & 1.044 \\
\hline q2 & Increases my ability to participate effectively. & 3.19 & .961 \\
\hline q3 & Gives me an updated feedback to evaluate my achievements. & 3.17 & 1.101 \\
\hline q1 & $\begin{array}{l}\text { Provides me with more opportunities for participating and exchanging ideas and } \\
\text { information with peers. }\end{array}$ & 3.16 & 1.179 \\
\hline q11 & $\begin{array}{l}\text { Provides a learning environment which helps me to generate and develop new } \\
\text { ideas. }\end{array}$ & 3.14 & 1.050 \\
\hline $\mathrm{q} 12$ & Activities on Moodle meet my learning needs. & 3.12 & 1.037 \\
\hline q14 & Develops my ability in problems-solving skills. & 3.01 & 1.030 \\
\hline q4 & Teaches me patience and endurance when doing assignments. & 2.87 & .982 \\
\hline q5 & Helps me to find methods to connect theoretical knowledge to real life situations. & 2.78 & 1.031 \\
\hline q8 & $\begin{array}{l}\text { Develops my ability to understand the relationship between my specialization and } \\
\text { other (interdisciplinary science). }\end{array}$ & 2.57 & 1.060 \\
\hline
\end{tabular}

Table 2. Means and SD of students' responses for Learning Motivation (LM) domain statements

\begin{tabular}{llcc}
\hline No & Statements & Mean & SD \\
\hline q20 & Develops my skill in self-regulation. & 3.31 & 1.082 \\
q24 & Develops positive attitudes to me towards subject matter. & 3.30 & 1.051 \\
q22 & Increases my interests in follow-up lectures and do more readings. & 3.28 & 1.034 \\
q17 & Makes learning more fun to me. & 3.24 & 1.148 \\
q21 & Increases my motives in doing team work. & 3.22 & 1.046 \\
q23 & Diversity of learning stimuli in Moodle increases my desires to complete 3.18 & 1.085 \\
q18 & assignments. & 3.16 \\
q19 & Increases self-confidence in doing my assignments. & 3.15 & 1.094 \\
q16 & Increase my motives to learn. & 3.11 & 1.111 \\
\hline
\end{tabular}


Table 3. Means and SD of students' responses for Students Collaboration and Communication (SCC) domain statements

\begin{tabular}{llll}
\hline No & Statements & Mean & SD \\
\hline q33 & Helps me to get lecture notes any time. & 3.91 & 1.233 \\
q31 & Develops my skills in searching for knowledge throughout web pages. & 3.72 & 1.005 \\
q34 & Develops my communicative skills in getting information. & 3.32 & 1.061 \\
q32 & Gives me more chance to participate effectively with peers in doing e-learning 3.29 & 1.076 \\
& activities. & \\
q25 & Provides learning environment for me and my peers based on social interaction. & 3.11 & 1.078 \\
q35 & Gives me more opportunities in to cooperate with peers in making decisions 3.07 & 1.110 \\
& related to learning. & 3.03 & 1.014 \\
q30 & Develops my skills in generating new ideas. & 2.98 & 1.072 \\
q27 & Decreases the gap between me and my peers. & 2.96 & 1.148 \\
q26 & Gives me enough opportunities to chat with peers out of lecture time. & 1.080 \\
q29 & I always get the support and help from my peers to complete the learning activities. 2.93 & .926 \\
q28 & Develops my ability in reflective thinking. & 2.90 & .92 \\
\hline
\end{tabular}

\section{Copyrights}

Copyright for this article is retained by the author(s), with first publication rights granted to the journal.

This is an open-access article distributed under the terms and conditions of the Creative Commons Attribution license (http://creativecommons.org/licenses/by/3.0/). 